\title{
THE USE OF GEOLOCATION \\ FOR COMPETITION ANALYSIS OF DESTINATIONS: APPLICATION TO THE HOTEL SUPPLY IN BARCELONA
}

\author{
María D. Illescas-Manzano ${ }^{1}$ \\ Sergio Martínez-Puertas ${ }^{2}$ \\ Manuel Sánchez-Pérez ${ }^{3}$
}

DOI: https://doi.org/10.31410/tmt.2020.585

\begin{abstract}
Geolocalization and the use of geographic information systems (GIS) have become fundamental tools in many disciplines because they can link databases and view the geographic information provided by these databases. Within the hotel context, geolocation and GIS can be used as tools that from a management perspective facilitate the evaluation of the competitive level existing in a tourist destination and from a consumer point of view facilitate their choice. This chapter tries to show the usefulness of geolocation through its application in the evaluation of the hotel supply in Barcelona (Spain).
\end{abstract}

Keywords: Tourist destination, Geolocation, Geographic Information Systems, Competition, Location.

\section{INTRODUCTION}

$\mathrm{N}$ owadays, technological advances are increasing the generation of geolocated information with new sources of information such as a smartphone or social networks, that provide new opportunities (Kitchin, 2013). In this context, the use of geolocation and Geographic Information Systems (GIS) are relevant tools to explore intensely the abundant information currently available in the "Big Data" era both from the perspective of researcher, professional or individual daily routine of people (Sui \& Goodchild, 2011). GIS can be conceived as an effective tool to link databases and geographic information, which allows an improvement in the analysis and visualization of features of data by location maps. The visualization of data through maps when we have multi-source databases in a complex process is one of the reasons for the success of the GIS (Roig-Tierno et al., 2013). Thus, the use of GIS allows users to spatially analyze phenomena of interest for researchers in many areas, and it has been used usually in science areas such as soil science, (Zhu et al., 2001), climatology (Bradley, 2002), or hidrology (Frankenberger, 1999) but less common in social science (Teixeira, 2018).

Recently, advances in the development of GIS have allowed companies and organizations to use it increasingly (Roig-Tierno et al., 2013) and its extension to fields where researchers have little prior knowledge of GIS (Teixeira, 2018). From a management perspective, the use of GIS help managers in the complex decision process, like location decision of firms. In addition, due to the increasing use of the Internet, GIS analysis is increasingly sophisticated, since we have tools that integrate GIS with the Internet, making GIS analysis very convenient for decision-making (Yang et al., 2014). Thus, the use of GIS makes possible a better understanding of geographical information and it is one of the reasons for its success (Ozimec et al., 2010).

University of Almería, st Sacramento (Almería) Spain

University of Almería, st Sacramento (Almería) Spain

University of Almería, st Sacramento (Almería) Spain 
From a theoretical perspective, the incorporation of GIS in social science research areas has promoted that spatial variables have an increasingly relevant role as descriptive and explanatory variables (Roig-Tierno et al., 2013).

The use of GIS in marketing research has also promoted the development of new fields such as geomarketing, which seek to satisfy consumer needs and increase the profitability of companies through the use of GIS (Baviera-Puig et al., 2016; Hess et al., 2004) or the geocompetition by mapping and locating a company's competitors (Roig-Tierno et al., 2013). Thus, GIS has become a relevant tool to achieve a competitive advantage and achieve greater efficiency in marketing campaigns (Guarda et al., 2019).

One of the fields that generates more geolocated information and that can benefit the most from the use of GIS is tourism (García-Palomares et al., 2015). Thus, in tourism research, GIS has been employed in tourism development analysis (Jin et al., 2019), identification of tourist hot spots (García-Palomares et al., 2015), or assessment of tourism destination (González-Ramiro et al., 2016) and it can be a powerful tool to manage and promote tourism destinations (Mango et al., 2020). In the tourism context, the hospitality sector also has explored the use of Geomarketing and GIS (Dušek et al., 2019; Feng \& Morrison, 2002) and the hospitality research has applied geolocation and GIS to analyse room price (Kim et al., 2020; Latinopoulos, 2018; Soler \& Gemar, 2018; Zhang et al., 20011b); hotel agglomeration and competition (Lee, 2015; Lee \& Jang, 2015; Urtasun \& Gutiérrez, 2017) or hotel location (Fang et al., 2019; Fang et al., 2020; Yang et al., 2015).

The purpose of this chapter is to illustrate the use of geolocation and GIS descriptively in the hotel sector and more specifically, the use of geolocation for an analysis of the existing competition in the hotel offer in the city of Barcelona.

\section{GEOLOCATION AND GIS IN HOSPITALITY}

In recent years, Yan et al., (2014) claimed for the incorporation of the use of geographic information system to analyze in a more complete and sophisticated way hotel industry. Hospitality scholars have increasingly attempted to incorporate the use of geolocation and GIS to address this issue and how the lodging industry could be affected by their geographic location, but analysis with spatial data requires more sophisticated techniques which account for spatial heterogeneity and spatial dependence (Nicholls \& Kim, 2019). Also, hospitality researchers have had to use techniques such as Geographically Weighted Regression (GWR) or Geographically Weighted Poisson Regression (GWPR) (Fotheringham et al., 2002) because the global models (conventional multivariate regressions) can hide the local relationship between the dependent and explanatory variables (Nicholls \& Kim, 2019). These advanced regressions techniques can be managed by programming with software such as R or GWR 4 Software or by advanced statistical packages such as ArcGIS.

One stream of research has investigated hotel location with GIS (Fang et al., 2019; Fang et al., 2020; Yang et al., 2015). For new hotels, geolocation is a useful tool to support location decisions, a crucial decision (Yang et al., 2012) because it is almost impossible to relocate a hotel after it has opened (Fang et al., 2019). With the right location decision, a hotel can enjoy higher occupancy (Luo \& Yang, 2016), it can attract more customers (Yang et al., 2012) because hotel location can significantly impact hotel choice (Chu \& Choi, 2000) and it can raise profitability 
(Luo \&Yang, 2016). Recently, hospitality research has analyzed hotel location decisions through geolocation and GIS to apply modelization methods to account for spatial heterogeneity and spatial autocorrelation. Fang et al. (2019) and Fang et al. (2020) incorporated GIS in the analysis of hotel location choice and they concluded that the factors which impact hotel location change across regions. Additionally, Fang et al. (2019) concluded that global model estimation may not capture efficiently the hotel location choice.

On the other hand, through geolocation and GIS, hospitality research has evaluated price determinants (Kim et al., 2020; Latinopoulos, 2018; Soler \& Gemar, 2018; Zhang et al., 20011b). For hotel room prices in Beijing, Zhang et al., (2011b) used GWR to obtain a hedonic price model, finding a significant spatial variation within all the independent variables. Similarly, Latinopoulos (2018) analyzed the effect of a sea view on hotel prices in Halkidiki, Greece, and found that its effect varies across areas. Both Soler \& Gemar (2018) with a sample of hotels in Malaga (Spain) and Kim et al. (2020) with a sample of hotels in Chicago found that the relationships between room price and hotel attributes and location attributes are spatially varying.

Additionally, spatial with geolocation and GIS hospitality research has investigated price competition and differentiation strategy (Lee, 2015), and agglomerations effect on hotel performance (Lee \& Jang, 2015; Urtasun \& Gutiérrez, 2017).

The purpose of this chapter is to show in a managerial way how the use of geolocation and GIS allows analysing the competitive intensity of the hotel sector in a destination.

\section{AGGLOMERATION AND COMPETITION IN THE HOTEL INDUSTRY}

On the one hand, from the Industrial Organization approach, the theoretical argumentation (Shaked \& Sutton, 1982) establishes a price decrease when there is an increase in the degree of local competition with empirical evidence that supports this negative effect of competition on price within the hotel sector (Abrate et al., 2012; Balaguer \& Pernias, 2013; Becerra et al., 2013), so that the greater the number of hotels the greater is the decrease in the average price of the room.

On the other hand, in contrast to the theory from the Industrial Organization approach, a positive relationship between the set of selected tourist activities available in an area and their economic result are proposed by the Central Place Theory (CPT) (King, 1984; Daniels, 2007) as hotels tend to be located next to each other to improve supply and efficiency and to be able to survive (Yang et al., 2012). Additionally, the Agglomeration Theory (McCann \& Folta, 2008) postulates that benefits can be obtained from hotel agglomeration, such as exogenous factors (other companies that attract tourists), reduction of the cost of consumer search leading to increased demand (Baum \& Haveman, 1997), or the creation of endogenous externalities. Based on these theories, a positive relationship between hotel benefits and agglomeration is postulated, which has been empirically supported within the hotel sector (Chung \& Kalnins, 2001; Lee \& Jang 2015; Silva, 2016).

However, the differentiation strategy can be affected by the hotel agglomeration. On the one hand, differentiation can reduce the risk of failure of hotels (Baum \& Mezias, 1992) and allows to reduce the possible negative effects associated with greater competition. Thus, lodging literature has promoted differentiated hotel agglomerations. On the other hand, hotels with great- 
er differentiation may be the most affected by agglomeration externalities (Chung \& Kalnins, 2001) since hotels less differentiation can capture most of the benefits of agglomeration, and depending on market demand, there is the possibility of benefits in undifferentiated agglomerations (Lee \& Jang, 2015), so differentiation may not be an adequate strategy. In addition, the Strategic Equilibrium Theory (Deephouse, 1999) propounds the dilemma between conformity or differentiation from competitors and postulates that the degree of differentiation of hotels is established based on competition (Kim et al., 2020).

\section{APPLICATION OF GEOLOCATION IN THE SPATIAL COMPETITION ANALYSIS: BARCELONA HOTELS}

Next, we are going to use geolocation to analyze the competitive intensity of a database that includes a sample of hotels in the city of Barcelona (one of the most important tourist cities in Europe) in 2017 when it was ranked the sixth place in the Top 15 European Cities - Total Bednights 2017 with 18,791,180 overnight stays (European Cities Marketing, 2018).

The sample of hotels was obtained with the combination of web analysis techniques together with an information system from an international tourism intermediary (Paulizt \& Napierala, 2017). Regarding the web analysis techniques, an online monitoring system was developed to crawl data directly from web pages of lodging establishments. This monitoring system was based on tools for tracking and data extraction from the Internet. Specifically, for this study the R software (Team R Core, 2020) was used through the "Rcrawler" package (Khalil, 2018; Khalil \& Fakir, 2017) for the development of the monitoring system. As a result, a sample with 217 hotels located in Barcelona was obtained and we can obtain the following information for each hotel in the sample:

- Hotel name.

- Hotel Age. number of years in operation for each hotel.

- Number of rooms. size of each hotel measure as total number of rooms.

- Category. Star rating of the hotel measured from one to five stars and officially assigned by the autonomous Government of Catalonia.

- Room Price. For each hotel, we obtained the yearly average room rate in euros for a standard double room during the year 2017. For a deeper analysis of competitor prices, we consider the standard double room because is the usual price employed in the hospitality research ( Sánchez-Perez et al., 2019) and the average room rate because room price may suffer variations caused by distribution channel, season, or the occurrence of commercial events. However, the average is more reliable since it is free of these price variations (Lee, 2015).

- Available services. For each hotel, we collect information about availability of several services, including hotel-style, food services, payment methods and sports activities (Yang et al., 2016; Latinopoulos, 2018; Soler et al., 2019). With this information, we consider a $V_{i}$ vector based on dummy variables related to each of the services considered.

- GPS coordinates. To geolocate the hotels in the sample, we crawl the GPS coordinates for all of them. Thus, we collect the Longitude and Latitude for each hotel.

Secondly, from the information provide by an international tourism wholesaler, we add the following information for each hotel in the sample: 
Table 1. Sample descriptive statistics for hotels in Barcelona

\begin{tabular}{|l|l|l|l|l|l|l|l|}
\multicolumn{1}{c|}{} & Mean & St. dev. & Min & $1^{\text {st }}$ Quart & Median & $3^{\text {rd }}$ Quart & Max \\
\hline Age & 2002.728 & 11.032 & 1865 & 2001 & 2004 & 2007 & 2016 \\
\hline Number of rooms & 102.507 & 87.787 & 5 & 52 & 79 & 113 & 500 \\
\hline Ronsumer average score & 7.061 & 2.157 & 0 & 7 & 7.8 & 8.1 & 9.4 \\
\hline Horizontal differentiation & 93.603 & 107.604 & 34.34 & 55.61 & 71.92 & 96.40 & 1224.16 \\
\hline Barcelona areas & 0.224 & 0.285 & 0 & 0 & 0 & 0.5 & 1 \\
\hline Airport Zone & $\%$ & Barcelona areas & $\%$ & & & \\
\hline Barrio Gotico & 0.461 & La Rabassada & 0.461 & & & \\
\hline Camp Nou & 7.373 & Las Ramblas & 9.677 & & & \\
\hline Ciutadella/Villa Olímpica & 1.843 & Parallel & 2.304 & & & \\
\hline Ciutat Vella/ El Raval & 1.382 & Paseo de Gracia & 7.373 & & & \\
\hline Diagonal Mar & 2.765 & Plaza Catalunya & 7.373 & & & \\
\hline Eixample & 25.806 & Poblenou & 1.843 & & & \\
\hline El Born & 3.687 & Puerto de Barcelona & 0.461 & & & \\
\hline El Guinardo & 0.461 & Sagrada Familia & 2.304 & & & \\
\hline Gracia & 1.843 & Sants-Montjuic & 6.912 & & & \\
\hline La Diagonal & 5.991 & Sarria-Sant Gervasi & 4.147 & & & \\
\hline La Maquinista & 0.461 & Vall D'Hebron & 0.461 & & & \\
\hline Category & $\%$ & & & & & \\
\hline 1 star & 0.922 & & & & & & \\
\hline 2 stars & 10.599 & & & & & & \\
\hline 3 stars & 32.719 & & & & & & \\
\hline 4 stars & 47.465 & & & & & & \\
\hline 5 stars & 8.295 & & & & & \\
\hline
\end{tabular}

Source: Own elaboration

- Area. This is the commercial zone for each hotel. We consider the 24 commercial areas traditionally defined in Barcelona by the intermediaries as geographical competition areas because is a common practice for a better analysis of the hotel competition (Balaguer \& Pernias, 2013) and hotel location choice (Yang et al., 2012).

- Consumers Average Score. The yearly average valuation made by the customers of each hotel in 2017. This rating made by the customers and published on the web portal is a numerical valuation ranging from zero (the worst evaluation) to ten (the best evaluation). Similar approaches were considered in the hospitality research to measure reputation information about hotels (Yang et al., 2016; Zhang et al., 2011a).

Finally, from the information of available services for each hotel included in the vector $V_{i}$ and from the information of commercial zones, we consider an index of horizontal differentiation:

- Hotel Differentiation. To measure the degree of services differentiation for each hotel $i$ respect to the hotel located in the same commercial zone $Z_{i}$, we consider the following index (Chisholm et al., 2010; Sánchez-Pérez et al., 2020):

$$
(\text { Hotel Differentiation })=\min _{j \in Z_{i}}\left(\cos ^{-1} \frac{V_{i} \cdot V_{j}}{\left\|V_{i}\right\| \cdot\left\|V_{j}\right\|}\right) /\left(\frac{\pi}{2}\right)
$$

It takes values between 0 (the minimum differentiation) and 1 (the maximum differentiation).

Table 1 shows the sample descriptive statistics obtained with all hotels in the sample. Now, for a better understanding of the extensive information contained in the database, we will make use of geolocation and mapping. With the GPS coordinates obtained in the previous stage and 
with the R package „sf” (Pebesma, 2018) a geographic database can be obtained with all the variables previously described. For the visualization of the information through maps, the $\mathrm{R}$ "mapview" package was used (Appelhans et al., 2019). The package "mapview" employs OpenStreetMap ${ }^{\circledR}$ to map the geographic information. Thus, we can visually analyze the hotel supply of the establishments included in the sample of hotels located in the city of Barcelona. First, we show the computer code to load the packages in $\mathrm{R}$ and access our sample of hotels:

>library(sf) \#To load the package sf

>library(mapview) \#To load the package mapview

\#To load the database with the sample of hotels in Barcelona\#

>Barcelona<-read.table (,Hotel Barcelona.csv', header $=\mathrm{T}$, sep $=={ }^{\prime \prime} \mid{ }^{\prime \prime}$, dec=' ${ }^{\prime}$ )

The object Barcelona is a data.frame object in $\mathrm{R}$ which includes two variables Longitude and Latitude with the GPS coordinates of each hotel. Next, with the function st _ as _ sf from "sf" package, we obtain a geolocated data frame:

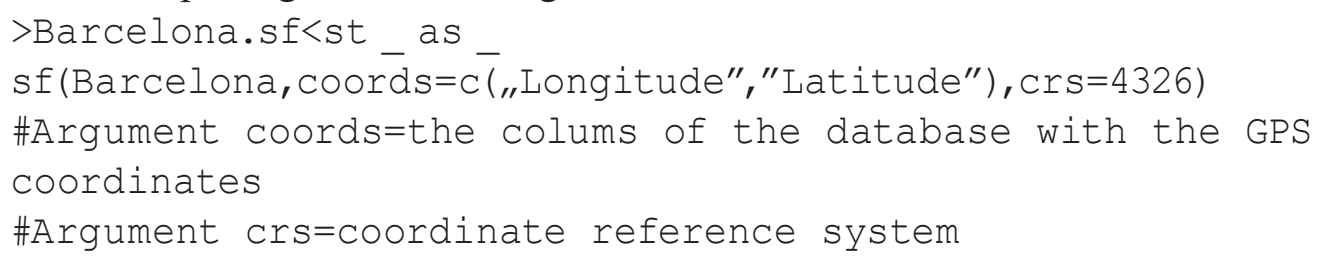

Through geolocation, we can visualize all the characteristics included in the database by mapping the sample of hotels. Figure 1 shows an interactive map with the distribution of hotels in the sample by commercial areas defined in Barcelona. The map, which contains all the variables in the database, is obtained with the function mapviev from "mapview" package:

>mapview(Barcelona, burst=TRUE, homebutton=FALSE, alpha.region=1)

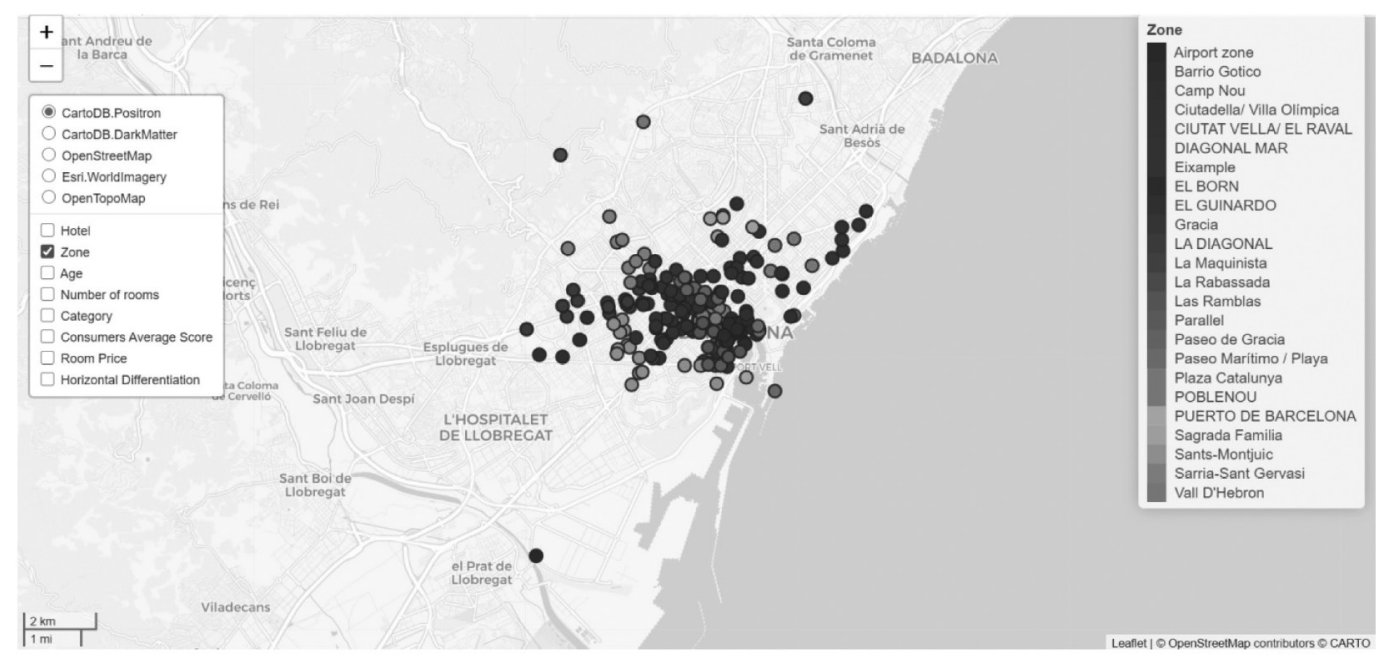

Figure 1. Hotel sample geolocation by commercial zone

Source: Own elaboration through the use of OpenStreetMap ${ }^{\circledR}$ and Contributors

With the left menu, we can mapping all variables includes in the database. Figure 2 map the hotels included in the sample by hotel category. Each hotel point in the map can show the features included in the dataset. This is very useful to hotel managers because they can better visualize the characteristics of hotels around their hotels and they can better take over the degree of competition intensity in the room price, online reputation, or service differentiation. 


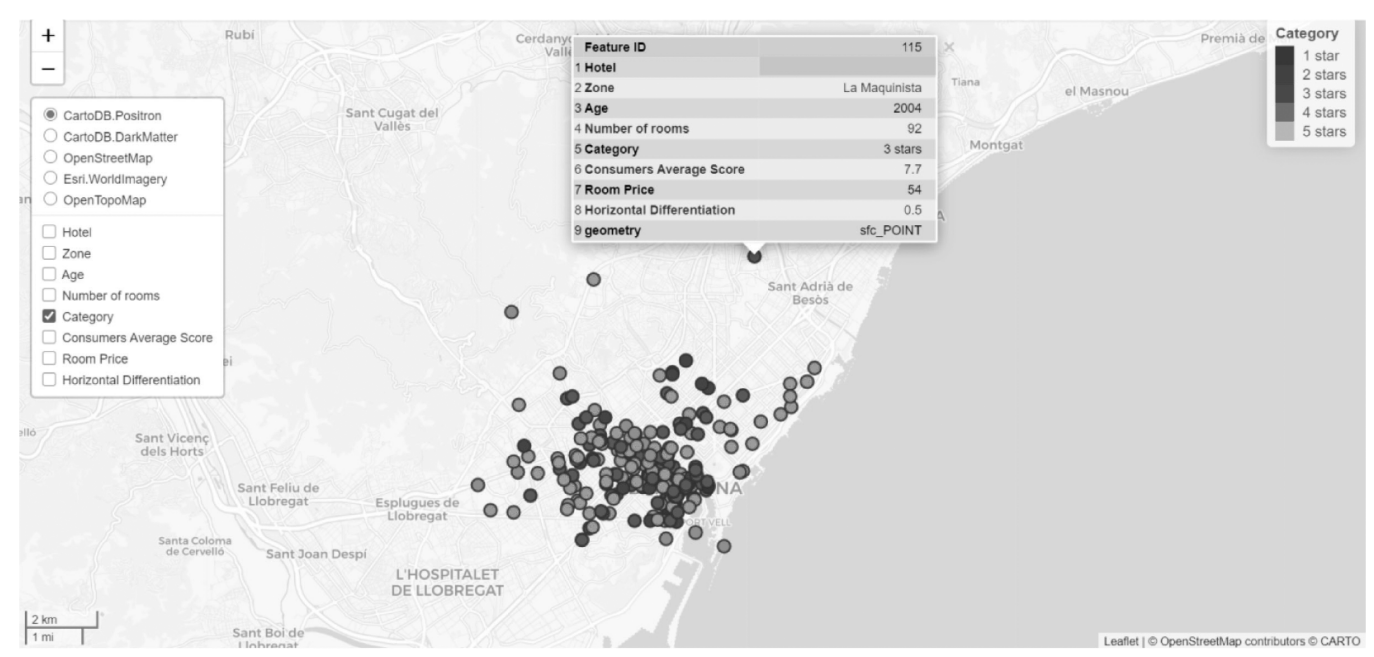

Figure 2. Hotel sample geolocation by hotel category

Source: Own elaboration through the use of OpenStreetMap ${ }^{\circledR}$ and Contributors

Table 2. Sample descriptive statistics for hotels in Las Ramblas

\begin{tabular}{|l|c|c|c|c|c|c|c|}
\cline { 2 - 8 } \multicolumn{1}{c|}{} & Mean & St. dev. & Min & $1^{\text {st }}$ Quart & Median & $3^{\text {rd }}$ Quart & Max \\
\hline Age & 1997 & 30.930 & 1865 & 2002 & 2005 & 2007 & 2013 \\
\hline Number of rooms & 98.71 & 67.209 & 14 & 45 & 83 & 131 & 255 \\
\hline Consumer average score & 6.833 & 2.464 & 0 & 6.2 & 7.7 & 8.2 & 9 \\
\hline Room price & 83.5 & 41.942 & 47.62 & 57.94 & 68.95 & 86.18 & 224.07 \\
\hline Horizontal Differentiation & 0.178 & 0.269 & 0 & 0 & 0 & 0.392 & 0.732 \\
\hline Category & $\%$ & & & & & & \\
\hline 1 star & 0 & & & & & & \\
\hline 2 stars & 14.286 & & & & & & \\
\hline 3 stars & 42.857 & & & & & & \\
\hline 4 stars & 33.333 & & & & & & \\
\hline 5 stars & 9.524 & & & & & & \\
\hline
\end{tabular}

Source: Own elaboration

To illustrate how geolocation can help hotel managers to carry out competitive analysis, we consider a hotel manager whose hotel is located in the commercial area 'Las Ramblas'. The descriptive statistics for all hotels in this commercial zone are showed in Table 2 . With $\mathrm{R}$, we can obtain a data.frame with only the hotels located in the area 'Las Ramblas':

$>$ Las _ Ramblas<-Barcelona[Zoneinoc(,Las Ramblas'),]

Additionally, Figure 3 shows the spatial distribution by hotel category and hotel differentiation in services in this zone:

$>$ mapview(Las Ramblas,zcol='Category',alpha.region=1) \#Figure $3 a$

>mapview(Las _ Ramblas,zcol='Hotel Differentiation', alpha.

region=1) \#Figure 3b

The hotel supply in 'Las Ramblas' shows a preeminence of hotels between 3 and 4 stars and where there are few 2 and 5 stars hotels. Regarding hotel differentiation in services, most of the hotels located in this area offer similar services and are little differentiated horizontally. 

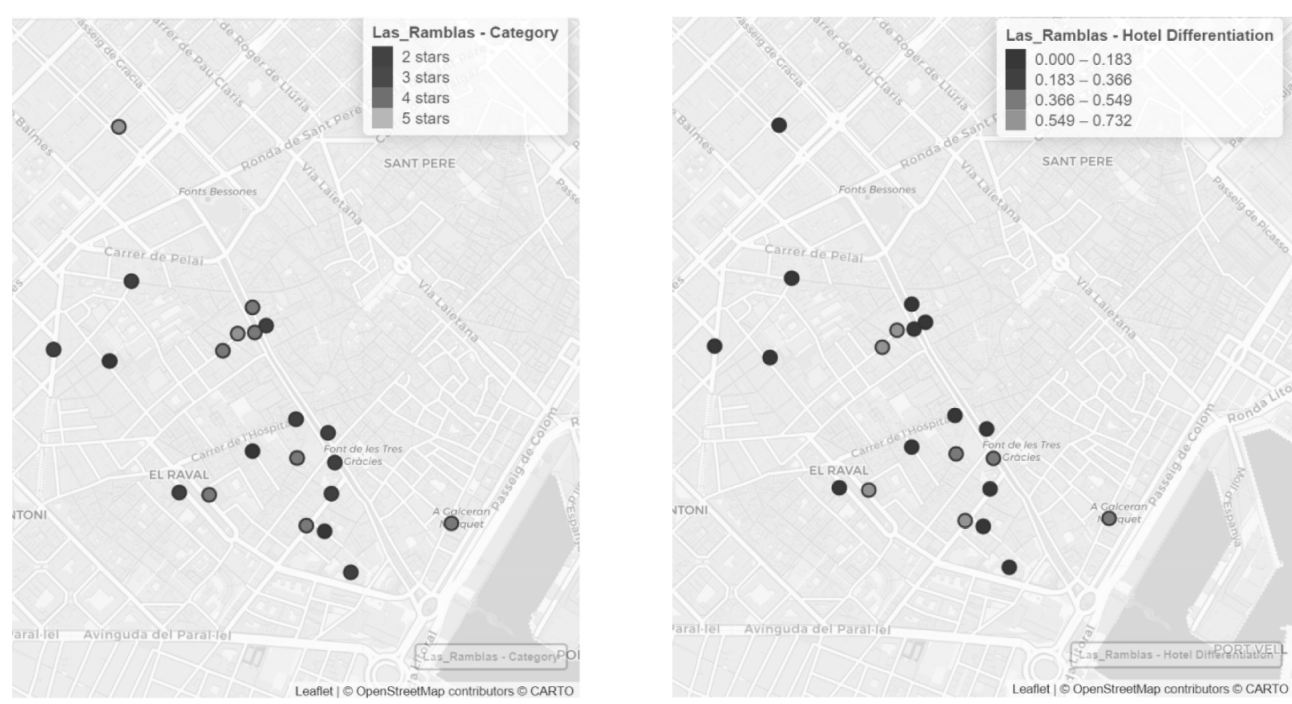

Figure 3. Spatial distribution by category and hotel differentiation in area 'Las Ramblas'.

Source: Own elaboration through the use of OpenStreetMap ${ }^{\circledR}$ and Contributors

Similarly, Figure 4 shows the spatial distribution for room price and consumer average score in 'Las Ramblas':

>mapview(Las _ Ramblas,zcol='Room Price',alpha.region=1)\#Figure $4 a$

>mapview(Las _ Ramblas,zcol='Consumers Average Score',alpha.

region=1)\#Figure 4b

Most hotels in this area have a room price between 50 and 80 euros, with just few hotels exceeding 100 euros, and only a hotel whose room price exceeds 200 euros. Concerning consumer score, this commercial area has a high online reputation, since the hotels located in it are highly valued by consumers except for a few hotels whose valuation is much lower than the rest of the hotels in the area and their managers must analyze the reasons why they are less valued than their direct competition.

In summary, 'Las Ramblas' area stands out for its offer of hotels between 3 and 4 stars where a few hotels have mainly differentiated their offer of services. It is an area well valued by previous consumers and the average room price is mostly between 50 and 80 euros per night.
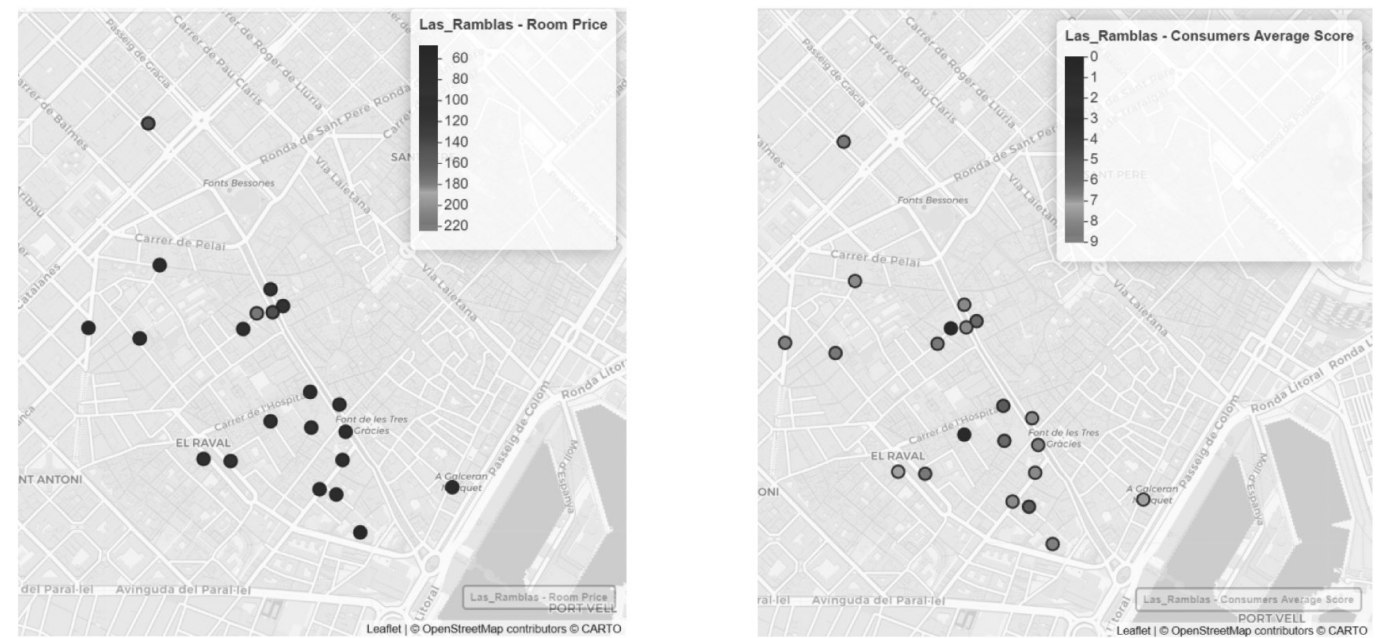

Figure 4. Spatial distribution by room price and consumer score in 'Las Ramblas'

Source: Own elaboration through the use of OpenStreetMap ${ }^{\circledR}$ and Contributors 
Table 3. Sample descriptive statistics for hotels in 'Barrio Gótico' and 'Paseo de Gracia'

\begin{tabular}{|c|c|c|c|c|c|c|c|}
\hline \multicolumn{8}{|c|}{ Barrio Gótico } \\
\hline & Mean & St. dev. & Min & $1^{\text {st }}$ Quart & Median & $3^{\text {rd }}$ Quart & Max \\
\hline Age & 2001 & 8.065 & 1981 & 1995 & 2003 & 2006 & 2013 \\
\hline Number of rooms & 70.12 & 52.321 & 9 & 37.75 & 60.50 & 78.50 & 197 \\
\hline Consumer average score & 6.269 & 1.927 & 0 & 5.925 & 6.450 & 7.575 & 8 \\
\hline Room price & 136.84 & 229.508 & 43.36 & 54.26 & 62.93 & 97.64 & 983.12 \\
\hline Horizontal Differentiation & 0.147 & 0.267 & 0 & 0 & 0 & 0.125 & 0.732 \\
\hline \multicolumn{8}{|c|}{ Paseo de Gracia } \\
\hline & Mean & St. dev. & Min & $1^{\text {st }}$ Quart & Median & $3^{\text {rd }}$ Quart & Max \\
\hline Age & 2005 & & 1997 & 2003 & 2007 & 2008 & 2010 \\
\hline Number of rooms & 103.9 & & 28 & 65 & 91 & 127.8 & 235 \\
\hline Consumer average score & 6.85 & & 0 & 7.25 & 7.9 & 8.125 & 8.7 \\
\hline Room price & 132.96 & & 73.58 & 103.16 & 114.62 & 143.29 & 277.49 \\
\hline Horizontal Differentiation & 0.327 & & 0 & 0 & 0.399 & 0.529 & 0.654 \\
\hline Barrio Gótico & & & \multicolumn{2}{|c|}{ Paseo de Gracia } & & & \\
\hline Category & $\%$ & & Category & $\%$ & & & \\
\hline $1 \mathrm{star}$ & 0 & & 1 star & 0 & & & \\
\hline 2 stars & 6.25 & & 2 stars & 0 & & & \\
\hline 3 stars & 50 & & 3 stars & 6.25 & & & \\
\hline 4 stars & 37.5 & & 4 stars & 68.75 & & & \\
\hline 5 stars & 6.25 & & 5 stars & 25 & & & \\
\hline
\end{tabular}

Source: Own elaboration

To illustrate how geolocation can help hotel firms in location decisions, we suppose that a company wants to open a new hotel in Barcelona and has considered for its location the area called 'Barrio Gótico' and the area called 'Paseo de Gracia'. The data.frame in R with two areas is obtained as follows:

>Loc_Decisions<-Barcelona[Zonein\%c(,Barrio Gotico','Paseo de Gracia'), ]

Table 3 describes the main measures for both commercial areas of the characteristics included in the analysis. Similar to the previous examples, R can show the spatial distribution for two areas (Figure 5).

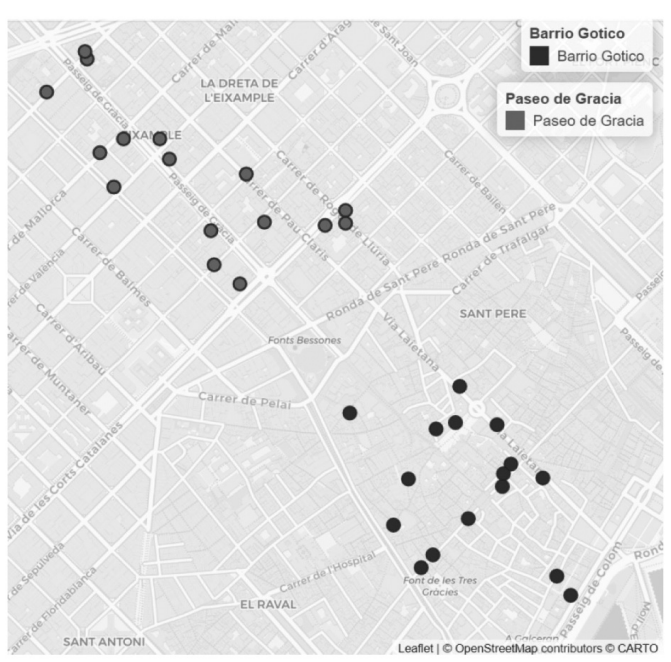

Figure 5. Spatial distribution for 'Paseo de Gracia' and 'Barrio Gótico' areas

Source: Own elaboration through the use of OpenStreetMap ${ }^{\circledR}$ and Contributors 
Through geolocation and mapping, we can analyze the characteristics of both areas and based on the results make a more accurate decision. Both areas have a similar number of hotel establishments and if we analyze the supply by the number of rooms available (Figure 6), we can show the number of rooms available in each of the establishments in both areas. We can see that, even though there is the same number of establishments, the bed supply available in each of them is generally greater in 'Paseo de Gracia' area than in 'Barrio Gótico' area. Similarly, hotels in the first zone are newer than hotels in the second zone.
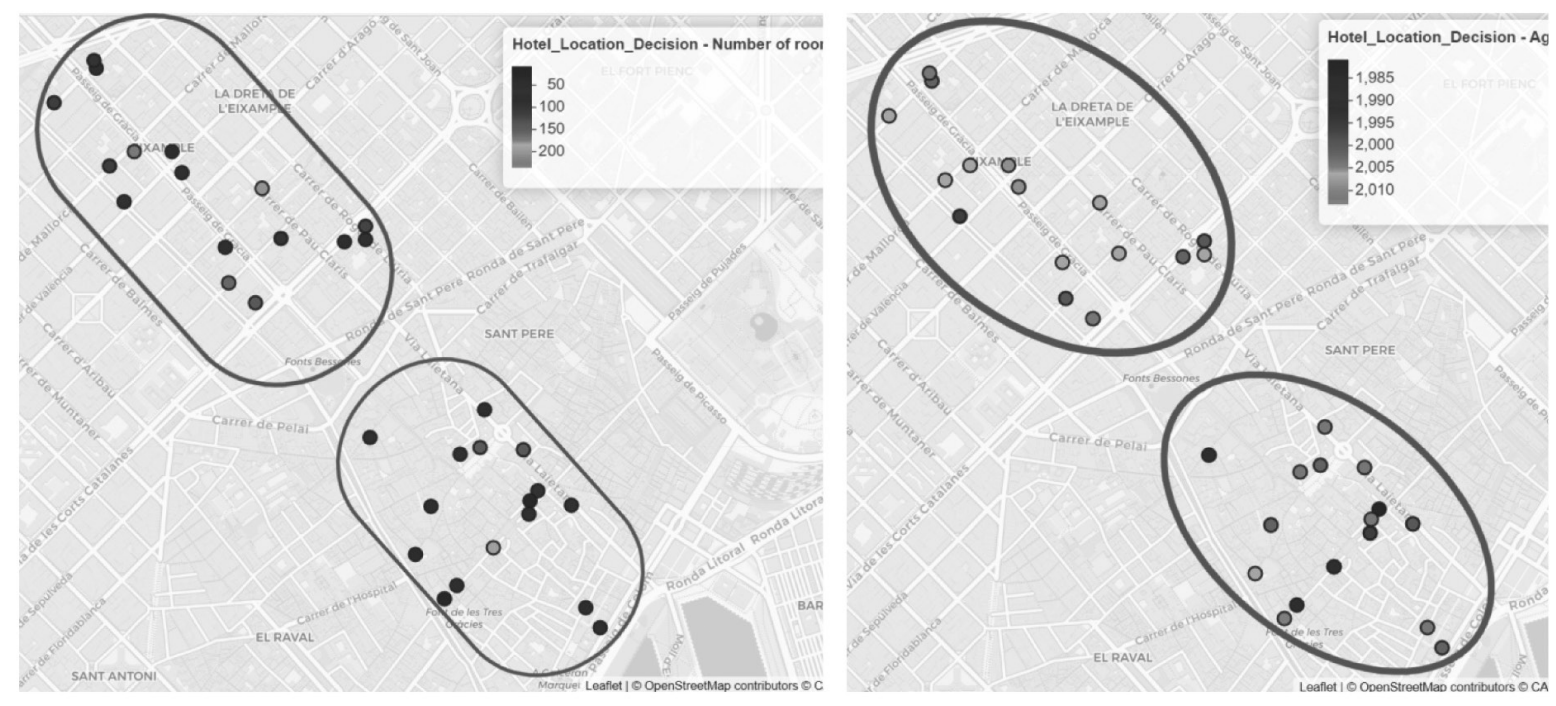

Figure 6. Spatial distribution by size and age in 'Paseo de Gracia' and 'Barrio Gótico' areas

Source: Own elaboration through the use of OpenStreetMap ${ }^{\circledR}$ and Contributors
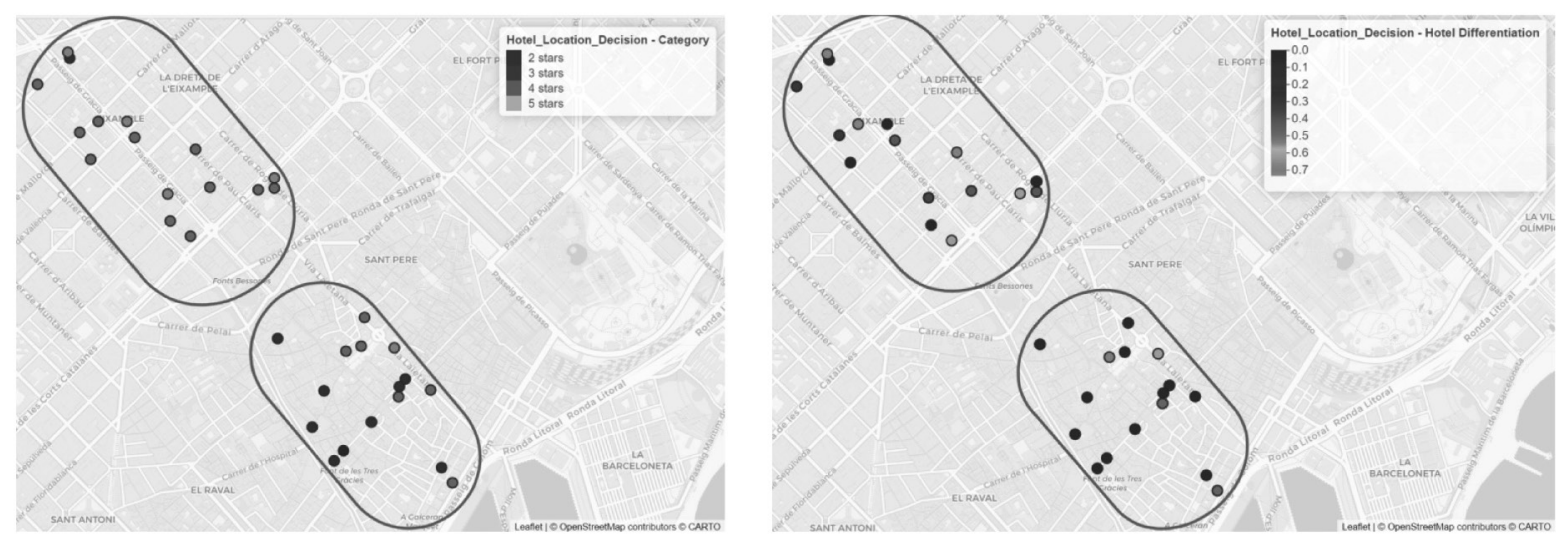

Figure 7. Spatial distribution by category and hotel differentiation in 'Paseo de Gracia' and 'Barrio Gótico' areas.

Source: Own elaboration through the use of OpenStreetMap ${ }^{\circledR}$ and Contributors

Figure 7 depicts the spatial distribution of hotel category and hotel differentiation in services in both zones. Most hotels in 'Paseo de Gracia' are hotels with 4 and 5 stars whereas hotels in 'Barrio Gótico' show a preeminence for a hotel with 3 and 4 stars, and just a few hotels of 2 and 5 stars. Thus, in the case of 'Paseo de Gracia' area, there is a hotel supply more vertical differentiated (Becerra et al., 2013; Makadok \& Ross, 2013; Silva, 2015) than 'Barrio Gotico' area. Regarding hotel differentiation in services, hotels located in Barrio Gótico offer similar services with some exceptions, whereas in 'Paseo de Gracia', services offered are wider and with more different services. 

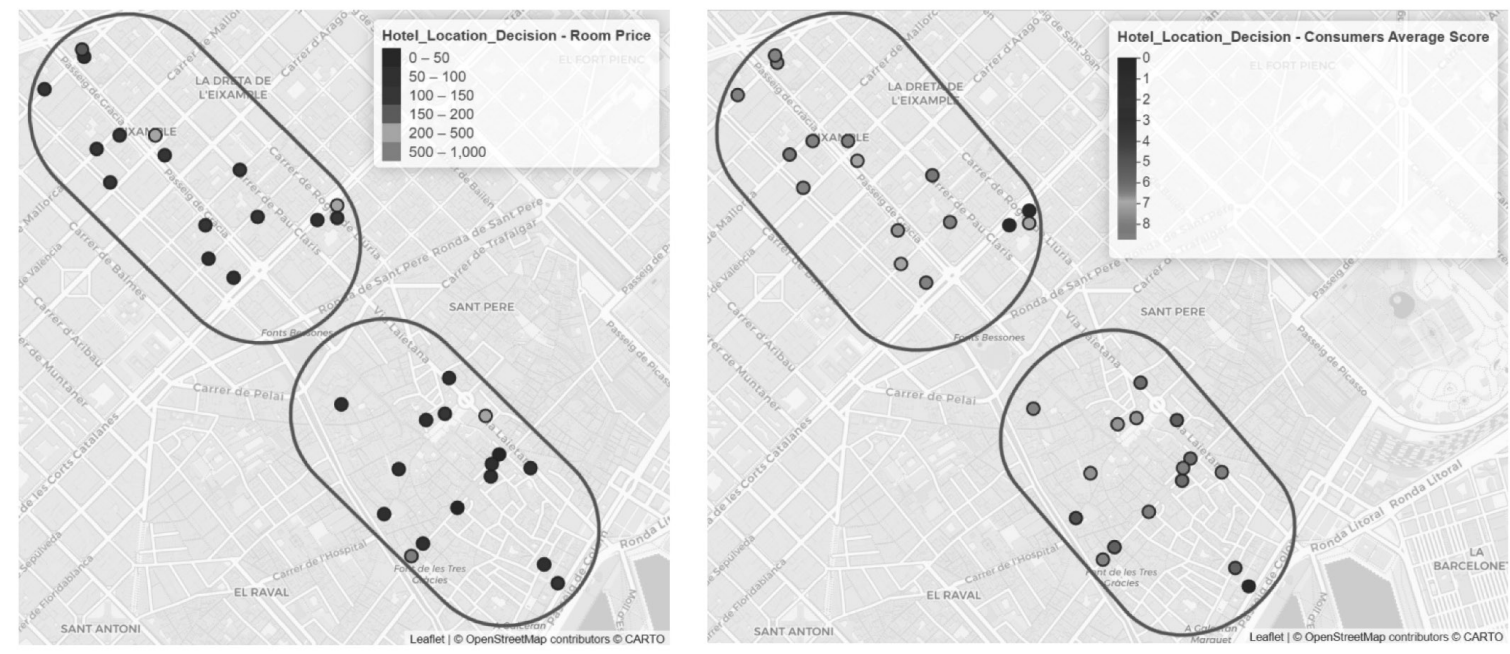

Figure 8. Spatial distribution by room price and hotel differentiation in 'Paseo de Gracia' and 'Barrio Gótico' areas.

Source: Own elaboration through the use of OpenStreetMap ${ }^{\circledR}$ and Contributors

Concerning room price, as a key competitive variable (Figure 8), 'Paseo de Gracia' area shows a greater number of establishments with prices between 100 and 150 euros per night, with two hotels with an average price between 150 and 200 euros and a single hotel with a price above 200 euros. Most hotels in 'Barrio Gótico' show a price between 50 and 100 euros and some of them with prices lower than 50 euros. Only one hotel sets prices above 200 euros and as an exception a hotel sets prices above 500 euros. Regarding the users' review, most of the hotels in 'Paseo de Gracia' area show a high reputation, close to 8 points (out 10) and some hotels show average scores around 6. Two hotels show very low evaluations. On the other hand, in the 'Barrio Gótico' area, hotels are usually valued at around 6 points, while there are some establishments whose valuation is close to 8 and only one hotel has a low score.

After this analysis, we can conclude that 'Paseo de Gracia' area has a supply of newer hotels and a higher number of available beds than the supply of 'Barrio Gótico'. The 'Paseo de Gracia' area has also hotels that are more vertically and horizontally differentiated than hotels in 'Barrio Gótico'. However, the online reputation among consumers in both areas is very similar and is only slightly higher in 'Paseo de Gracia'. Finally, the room price in 'Paseo de Gracia' is usually between 100 and 150 euros while in 'Barrio Gótico' the price is usually between 50 and 100 euros. With the information, the company can make a better decision about the location of a new hotel in Barcelona, and provides more accurate details about the hotel.

\section{FUTURE RESEARCH DIRECTIONS}

From a methodological point of view, the use of geolocation and GIS could promote the use of modelization techniques that can account for spatial heterogeneity and spatial autocorrelation. These modelization techniques can bring an alternative analysis of competition in the lodging industry more accurate than traditional techniques (Nicholls, 2019).

The geographic information found on the Internet can be crawled with a dynamic monitoring system dynamic that allows to constantly update the information of each establishment and consequently allows to monitor the degree of competition in a destination. 


\section{CONCLUSION}

This chapter tries to illustrate the use of geolocation within the hotel context and specifically how through the use of geolocation and GIS the degree of hotel competitive intensity in a tourist destination can be evaluated. The incorporation of geolocation in the analysis of hotel competition provides more complete and accurate information on each of the areas or zones within the same tourist destination and allows a better evaluation of the competitiveness between these areas, in line with the interest in evaluating the competitiveness that exists within the current tourism context (World Economic Forum, 2019). Finally, the incorporation of geolocation is also relevant for improving the consumer's hotel choice process.

\section{REFERENCES}

Abrate, G., Fraquelli, G., \& Viglia, G. (2012). Dynamic pricing strategies: evidence from European hotels. International Journal of Hospitality Management, 31(1), 160-168. https://doi. org/10.1016/j.ijhm.2011.06.003

Appelhans, T., Detsch, F., Reudenbach, C., \& Woellauer, S., (2019). mapview: Interactive Viewing of Spatial Data in R. R package version 2.7.0. https://CRAN.R-project.org/package $=$ mapview

Balaguer, J., \& Pernías, J.C. (2013). Relationship between spatial agglomeration and hotel prices. Evidence from business and tourism consumers. Tourism Management, 36, 391-400. https://doi.org/10.1016/j.tourman.2012.10.004

Baum, J. A., \& Haveman, H. A. (1997). Love thy neighbor? Differentiation and agglomeration in the Manhattan hotel industry, 1898-1990. Administrative Science Quarterly, 42(2), 304-338. https://doi.org/10.2307/2393922

Baum, J.A., \& Mezias, S.J. (1992). Localized competition and organizational failure in the Manhattan hotel industry, 1898-1990. Administrative Science Quarterly, 37(4), 580-604. https:// doi.org/10.2307/2393473

Baviera-Puig, A., Buitrago-Vera, J., \& Escriba-Perez, C. (2016). Geomarketing models in supermarket location strategies. Journal of Business Economics and Management, 17(6), 12051221. https://doi.org/10.3846/16111699.2015.1113198

Becerra, M., Santaló, J., \& Silva, R. (2013). Being better vs. being different: Differentiation, competition, and pricing strategies in the Spanish hotel industry. Tourism Management, 34, 71-79. https://doi.org/10.1016/j.tourman.2012.03.014

Bradley, A. V., Thornes, J. E., Chapman, L., Unwin, D., \& Roy, M. (2002). Modelling spatial and temporal road thermal climatology in rural and urban areas using a GIS. Climate Research, 22(1), 41-55.

Chisholm, D.C., McMillan, M.S., \& Norman, G. (2010). Product differentiation and film- programming choice: do first-run movie theatres show the same films? Journal of Cultural Economics, 34, 131-145. https://doi.org/10.1007/s10824-010-9118-y

Chu, R. K., \& Choi, T. (2000). An importance-performance analysis of hotel selection factors in the Hong Kong hotel industry: a comparison of business and leisure travellers. Tourism Management, 21(4), 363-377. https://doi.org/10.1016/S0261-5177(99)00070-9

Chung, W., \& Kalnins, A. (2001). Agglomeration effects and performance: a test of the Texas lodging industry. Strategic Management Journal, 22(10), 969-988. https://doi.org/10.1002/ smj.178

Daniels, M.J. (2007). Central place theory and sport tourism impacts. Annals of Tourism Research, 34(2), 332-347. https://doi.org/10.1016/j.annals.2006.09.004 
Deephouse, D. L. (1999). To be different, or to be the same? It's a question (and theory) of strategic balance. Strategic Management Journal, 20(2), 147-166. https://doi.org/10.1002/ (SICI)1097-0266(199902)20:2\%3C147::AID-SMJ11\%3E3.0.CO;2-Q

Dušek, R., Štumpf, P., \& Vojtko, V. (2019). Geomarketing: Tool for consumer spending estimation in the Czech tourism \& hospitality market. Global Business \& Finance Review (GBFR), 24(1), 14-26. http://dx.doi.org/10.17549/gbfr.2019.24.1.14

European Cities Marketing, 2018. European Cities Marketing Benchmarking Report 2018. https://www.europeancitiesmarketing.com/european-cities-marketing-benchmarking-report-2018-shows-the-continuous-growth-of-european-city-tourism/

Fang, L., Li, H., \& Li, M. (2019). Does hotel location tell a true story? Evidence from geographically weighted regression analysis of hotels in Hong Kong. Tourism Management, 72, 78 91. https://doi.org/10.1016/j.tourman.2018.11.010

Fang, L., Xie, Y., Yao, S., \& Liu, T. (2020). Agglomeration and/or differentiation at regional scale? Geographic spatial thinking of hotel distribution-a case study of Guangdong, China. Current Issues in Tourism, 1-17. https://doi.org/10.1080/13683500.2020.1792852

Feng, R., \& Morrison, A. M. (2002). GIS applications in tourism and hospitality marketing: A case in Brown County, Indiana. Anatolia, 13(2), 127-143. https://doi.org/10.1080/13032917. 2002.9687129

Fotheringham, A. S., Brunsdon, C., \& Charlton, M. (2002). Geographically weighted regression: the analysis of spatially varying relationships. John Wiley \& Sons.

Frankenberger, J. R., Brooks, E. S., Walter, M. T., Walter, M. F., \& Steenhuis, T. S. (1999). A GISbased variable source area hydrology model. Hydrological processes, 13(6), 805-822. https:// doi.org/10.1002/(SICI)1099-1085(19990430)13:6\%3C805::AID-HYP754\%3E3.0.CO;2-M

García-Palomares, J. C., Gutiérrez, J., \& Mínguez, C. (2015). Identification of tourist hot spots based on social networks: A comparative analysis of European metropolises using photo-sharing services and GIS. Applied Geography, 63, 408-417. https://doi.org/10.1016/j.apgeog.2015.08.002

González-Ramiro, A., Gonçalves, G., Sánchez-Ríos, A., \& Jeong, J. S. (2016). Using a VGI and GIS-based multicriteria approach for assessing the potential of rural tourism in Extremadura (Spain). Sustainability, 8(11), 1144. https://doi.org/10.3390/su8111144

Guarda, T., Augusto, M. F., \& Lopes, I. (2019, June). Geographic market intelligence as a competitive advantage. Paper presented at $201914^{\text {th }}$ Iberian Conference on Information Systems and Technologies (CISTI), Coimbra, Portugal, 2019, (pp. 1-5). IEEE. https://doi. org/10.23919/CISTI.2019.8760856

Hess, R. L., Rubin, R. S., \& West Jr, L. A. (2004). Geographic information systems as a marketing information system technology. Decision Support Systems, 38(2), 197-212. https://doi. org/10.1016/S0167-9236(03)00102-7

Jin, C., Xu, J., \& Huang, Z. (2019). Spatiotemporal analysis of regional tourism development: A semiparametric Geographically Weighted Regression model approach. Habitat International, 87, 1-10. https://doi.org/10.1016/j.habitatint.2019.03.011

Khalil, S. (2018). Rcrawler: Web Crawler and Scraper. $R$ package version 0.1.9-1. https:// CRAN.R-project.org/package $=$ Rcrawler

Khalil, S., \& Fakir, M. (2017). RCrawler: An R package for parallel web crawling and scraping. SoftwareX, 6, 98-106. https://doi.org/10.1016/j.softx.2017.04.004

Kim, J., Jang, S., Kang, S., \& Kim, S. J. (2020). Why are hotel room prices different? Exploring spatially varying relationships between room price and hotel attributes. Journal of Business Research, 107, 118-129. https://doi.org/10.1016/j.jbusres.2018.09.006 
Kim, M., Roehl, W., \& Lee, S. K. (2020). Different from or similar to neighbors? An investigation of hotels' strategic distances. Tourism Management, 76, 103-960. https://doi.org/10.1016/j. tourman.2019.103960

King, L. (1984). Central Place Theory. Beverly Hills: Sage.

Kitchin, R. (2013). Big data and human geography: Opportunities, challenges and risks. Dialogues in Human Geography, 3(3), 262-267. https://doi.org/10.1177/2043820613513388

Latinopoulos, D. (2018). Using a spatial hedonic analysis to evaluate the effect of sea view on hotel prices. Tourism Management, 65, 87-99. https://doi.org/10.1016/j.tourman.2017.09.019

Lee, S.K. (2015). Quality differentiation and conditional spatial price competition among hotels. Tourism Management, 46, 114-122. https://doi.org/10.1016/j.tourman.2014.06.019

Lee, S. K., \& Jang, S. (2015). Conditional agglomeration externalities in lodging markets. Journal of Hospitality y Tourism Research, 39, 540-559. https://doi.org/10.1177\%2F1096348013491605

Luo, H., \& Yang, Y. (2016). Intra-metropolitan location choice of star-rated and non-rated budget hotels: The role of agglomeration economies. International Journal of Hospitality Management, 59, 72-83. https://doi.org/10.1016/j.ijhm.2016.09.007

Makadok, R., \& Ross, D. G. (2013). Taking industry structuring seriously: A strategic perspective on product differentiation. Strategic Management Journal, 34(5), 509-532. https://doi. org/10.1002/smj.2033

Mango, J., Çolak, E., \& Li, X. (2020). Web-based GIS for managing and promoting tourism in sub-Saharan Africa. Current Issues in Tourism, 1-17. https://doi.org/10.1080/13683500.201 9.1711028

McCann, B.T., \& Folta, T.B. (2008). Location matters: where we have been and where we might go in agglomeration research. Journal of Management, 34(3), 532-565. https://doi. org/10.1177\%2F0149206308316057

Nicholls, S., \& Kim, J. (2019). Spatial is special: The need to consider spatial effects in leisure research. Leisure Sciences, 1-21. https://doi.org/10.1080/01490400.2019.1600441

Ozimec, A. M., Natter, M., \& Reutterer, T. (2010). Geographical information systems-based marketing decisions: Effects of alternative visualizations on decision quality. Journal of Marketing, 74(6), 94-110. https://doi.org/10.1509\%2Fjmkg.74.6.94

Pawlicz, A., \& Napierala, T. (2017). The determinants of hotel room rates: an analysis of the hotel industry in Warsaw, Poland. International Journal of Contemporary Hospitality Management 29, 571-588. https://doi.org/10.1108/IJCHM-12-2015-0694

Pebesma, E. J. (2018). Simple features for R: Standardized support for spatial vector data. The $R$ Journal, 10(1), 439-446. https://doi.org/10.32614/RJ-2018-009

Roig-Tierno, N., Baviera-Puig, A., \& Buitrago-Vera, J. (2013). Business opportunities analysis using GIS: the retail distribution sector. Global Business Perspectives, 1(3), 226-238. https://doi.org/10.1007/s40196-013-0015-6

Sánchez-Pérez, M., Illescas-Manzano, M. D., \& Martínez-Puertas, S. (2019). Modeling hotel room pricing: A multi-country analysis. International Journal of Hospitality Management, 79, 89-99. https://doi.org/10.1016/j.ijhm.2018.12.014

Sánchez-Pérez, M., Illescas-Manzano, M. D., \& Martínez-Puertas, S. (2020). You're the only One, or Simply the Best. Hotels differentiation, competition, agglomeration, and pricing. International Journal of Hospitality Management, 85, 102362. https://doi.org/10.1016/j. ijhm.2019.102362

Shaked, A., \& Sutton, J. (1982). Relaxing price competition through product differentiation. The Review of Economic Studies, 49(1), 3-13. https://doi.org/10.2307/2297136

Silva, R. (2015). Multimarket contact, differentiation, and prices of chain hotels. Tourism Management, 48, 305-315. https://doi.org/10.1016/j.tourman.2014.11.006 
Silva, R. (2016). Competition and demand effects of geographic distance to rivals. Service Industries Journal, 36(1-2), 37-57. https://doi.org/10.1080/02642069.2016.1138470

Soler, I. P., \& Gemar, G. (2018). Hedonic price models with geographically weighted regression: An application to hospitality. Journal of Destination Marketing \& Management, 9, 126-137. https://doi.org/10.1016/j.jdmm.2017.12.001

Sui, D., \& Goodchild, M. (2011). The convergence of GIS and social media: challenges for GIScience. International Journal of Geographical Information Science, 25(11), 1737-1748. https:// doi.org/10.1080/13658816.2011.604636

Team R Core, 2020. R: A language and environment for statistical computing and graphics The R Foundation for Statistical Computing, Vienna, Austria. http://www.R-project.org/.

Teixeira, S. (2018). Qualitative geographic information systems (GIS): An untapped research approach for social work. Qualitative Social Work, 17(1), 9-23. https://doi. org/10.1177\%2F1473325016655203

Urtasun, A., \& Gutiérrez, I. (2017). Clustering benefits for upscale urban hotels. International Journal of Contemporary Hospitality Management, 29(5), 1426-1446. https://doi. org/10.1108/IJCHM-10-2015-0583

World Economic Forum (2019). The Travel and Tourism Competitiveness Report 2019. https:// www.weforum.org/reports/the-travel-tourism-competitiveness-report-2019

Yang, Y., Luo, H., \& Law, R. (2014). Theoretical, empirical, and operational models in hotel location research. International Journal of Hospitality Management, 36, 209-220. https://doi. org/10.1016/j.ijhm.2013.09.004

Yang, Y., Mueller, N.J., \& Croes, R.R. (2016). Market accessibility and hotel prices in the Caribbean: the moderating effect of quality-signaling factors. Tourism Management, 56, 40-51. https://doi.org/10.1016/j.tourman.2016.03.021

Yang, Y., Tang, J., Luo, H., \& Law, R. (2015). Hotel location evaluation: A combination of machine learning tools and web GIS. International Journal of Hospitality Management, 47, 14-24. https://doi.org/10.1016/j.ijhm.2015.02.008

Yang, Y., Wong, K. K., \& Wang, T. (2012). How do hotels choose their location? Evidence from hotels in Beijing. International Journal of Hospitality Management, 31(3), 675-685. https:// doi.org/10.1016/j.jhm.2011.09.003

Zhang, Z., Ye, Q., \& Law, R. (2011a). Determinants of hotel room price: an exploration of travelers' hierarchy of accommodation needs. International Journal of Contemporary Hospitality Management, 23(7), 972-981. https://doi.org/10.1108/09596111111167551

Zhang, H., Zhang, J., Lu, S., Cheng, S., \& Zhang, J. (2011b). Modeling hotel room price with geographically weighted regression. International Journal of Hospitality Management, 30(4), 1036-1043. https://doi.org/10.1016/j.ijhm.2011.03.010

Zhu, A. X., Hudson, B., Burt, J., Lubich, K., \& Simonson, D. (2001). Soil mapping using GIS, expert knowledge, and fuzzy logic. Soil Science Society of America Journal, 65(5), 14631472. https://doi.org/10.2136/sssaj2001.6551463x 
